\title{
Bacteroides tectus
}

National Cancer Institute

\section{Source}

National Cancer Institute. Bacteroides tectus. NCI Thesaurus. Code C86178.

A species of obligately anaerobic, Gram-negative, rod shaped bacteria assigned to the phylum Bacteroidetes. This species is nonmotile, non-spore forming, indole and catalase negative, does not hydrolyze esculin and is susceptible to penicillin. B. tectus is found in the oral cavity of cats as well as in cat and dog wounds. 